\title{
NUTRIENT WASTE LOAD FROM VANAME SHRIMP (Litopeneaus vannamei) AND ANALYSIS OF LAND SUITABILITY BASED ON WATER QUALITY CRITERIA IN EARTH IN EAST RAWAJITU PROSPEROUS
}

\author{
R. Aken Yugo ${ }^{* 1}$, Eko Effendi ${ }^{1}$, Herman Yulianto ${ }^{1}$
}

\begin{abstract}
Bumi Dipasena Sejahtera as part of Bumi Dipasena, which is managed by PT. Dipasena Citra Darmaja is the largest shrimp farming in Southeast Asia. Since operating in 1980, Bumi Dipasena has made production up to 200 tons/day. However, the current condition shows a decrease in total production to $30-40$ tons/day from 16.000 operated ponds. Decreasing production is caused by declining water quality. This study aims to find out about nutrient loading and water suitability based on water quality criteria. Nutrient loading is determined from total production calculated from three different ponds. Suitability analysis was conducted by matching and scoring methods based on water quality measured at 7 sites in the inlet, outlet, and pond site. The result shows that nutrient loading has the highest value at the highest production. Water suitability analysis both of inlet and ponds include in suit marginal class (S3).
\end{abstract}

Keywords: nutrient loading, suitability, water quality, shrimp

\section{Pendahuluan}

Bumi Dipasena Sejahtera terletak di kawasan pertambakan udang vaname (Bumi Dipasena) yang dahulu di kelola oleh PT Dipasena Citra Darmaja. Sejak beroperasi pada tahun 1980-an, Bumi Dipasena telah memberikan kontribusi positif dengan total produksi mencapai 30 juta dolar AS pada tahun 1992 dengan total produksi mencapai 200 ton/hari, hingga pada tahun 1997 menjadi produsen udang terbesar kedua di Dunia (Fadilasari, 2012). Namun, sejak terputus dari perusahaan, Bumi Dipasena mengalami penurunan produksi yang cukup signifikan yaitu menjadi $30-40$ ton/hari dari total
16.000 petak tambak yang beroperasi (Daud, 2018).

Rendahnya produktivitas tambak di Bumi Dipasena ini kemungkinan dipengaruhi oleh beberapa faktor seperti penyakit, kondisi lingkungan dan kualitas air yang menurun. Kondisi lingkungan dan kualitas air merupakan salah satu faktor penentu yang memberikan pengaruh signifikan terhadap pertumbuhan udang vaname yang ada di tambak dan bermuara terhadap tinggi rendahnya produktivitas udang vaname yang dihasilkan. Poxton (2003) menyatakan bahwa setiap komoditas yang dibudidayakan di tambak, menuntut kualitas air yang berbeda untuk tumbuh secara

\footnotetext{
*E-mail: akend17@gmail.com

${ }^{1}$ Jurusan Perikanan dan Kelautan, Fakultas Pertanian, Universitas Lampung

Jl. Prof. S. Brodjonegoro No.1 Gedong Meneng Bandar Lampung, 35145
} 
optimum. Selanjutnya, pengaruh kualitas air terhadap organisme akuatik tersebut tercermin pada pertumbuhan dan sintasannya.

Buangan limbah budidaya selama operasional merupakan salah satu penyebab utama terjadinya penurunan kualitas lingkungan perairan. Hal ini disebabkan karena beban limbah mengandung konsentrasi bahan organik yang tinggi serta nutrien sebagai konsekuensi dari masukan aquainput dalam budidaya yang menghasilkan sisa pakan dan feses yang terlarut ke dalam perairan sekitarnya (Boyd et al., 1998; Horowitz \& Horowitz, 2000; Montoya \& Velasco, 2000). Dalam perikanan budidaya secara komersial sebanyak 30\% dari total pakan yang diberikan tidak dikonsumsi dan sekitar $25-30 \%$ dari pakan yang dikonsumsi tersebut akan diekskresikan (McDonald et al., 1996). Jumlah nitrogen (N) dan fosfor (P) yang ada dalam pakan akan diretensikan dalam daging antara 25 $30 \%$, selebihnya terbuang ke lingkungan perairan (Avnimelech, 2000).

Kajian terkait dengan kesesuaian perairan dan beban limbah budidaya menjadi penting untuk dilakukan sebagai salah satu upaya dalam mengantisipasi adanya penurunan kelayakan habitat dan dampaknya terhadap wilayah pesisir. Selain itu, informasi yang didapatkan tersebut bisa dimanfaatkan sebagai informasi dasar pengembangan budidaya yang lebih optimal, ramah lingkungan dan berkelanjutan.

Penelitian ini bertujuan untuk mengetahui tingkat kesesuaian perairan di Bumi Dipasena Sejahtera serta menganalisis beban limbah yang dihasilkan oleh tambak udang vaname yang dikelola dengan skala semi intensif.

\section{Metode}

Penelitian ini dilaksanakan pada bulan Maret - Mei 2019 di Bumi Dipasena Sejahtera, Rawajitu Timur. Analisis sampel air dilakukan di Laboratorium Analisis Politeknik Negeri Lampung. Alat yang digunakan dalam penelitian meliputi alat ukur kualitas air (termometer, refraktometer, DO Kit, dan $\mathrm{pH}$ meter) dan alat pengambilan sampel (botol film, gayung, dan ember). Selanjutnya sampel air dianalisis di laboratorium untuk mengetahui konsentrasi amonia $\left(\mathrm{NH}^{3}\right)$, nitrit $\left(\mathrm{NO}^{2}\right)$, nitrat $\left(\mathrm{NO}^{3}\right)$, dan TSS (Total Suspended Solids).

Penentuan lokasi pengambilan sampel ini berdasarkan kebutuhan data yang mengacu pada analisis yang digunakan yaitu analisis kesesuaian, analisis beban limbah, dan analisis kapasitas lingkungan. Oleh karena itu lokasi pengambilan sampel dibagi menjadi 7 stasiun yang mewakili perairan inlet dan outlet serta 3 tambak budidaya. Tiga petak tambak yang akan digunakan dalam penelitian ini memiliki luas $2.000 \mathrm{~m}^{2}$ dengan kedalaman yang berkisar antara $60-90 \mathrm{~cm}$ dari dasar tambak serta dilengkapi dengan sistem aerasi berupa kincir sebanyak 2 buah kincir per tambak. Selanjutnya, benur vaname yang digunakan adalah benur berumur 10 hari (PL-10) yang diperoleh dari hatchery kemudian ditebar dengan padat penebaran 45.000 ekor/tambak $\left(23 \mathrm{ekor} / \mathrm{m}^{2}\right)$ dan dipelihara selama 60 hari. Pakan yang digunakan adalah pakan komersial 
(pellet) yang diberikan dengan metode pemberian pakan dengan mengacu pada feeding program yang terdapat dalam kemasan pakan. Perubahan dosis pakan disesuaikan dengan hasil sampling bobot udang yang dilakukan setiap lima hari.

Metode analisis kesesuaian yang digunakan yaitu skoring dan pembobotan yang dilakukan untuk mengetahui tingkat kelayakan perairan terhadap kegiatan budidaya udang vaname. Metode skoring yang dilakukan mengacu pada matriks kesesuaian yang telah disusun sesuai dengan baku mutu yang telah ditetapkan. Penentuan nilai/skoring ini dilakukan untuk memberikan nilai/bobot pada setiap variabel karena setiap variabel memiliki peranan serta pengaruh yang berbeda dalam menunjang kehidupan suatu komoditas. Metode perhitungan skor total penentuan kelas kesesuaian mengikuti metode yang telah ditetapkan oleh Departemen Kelautan dan Perikanan (2002). Tingkat kesesuaian perairan menurut Trisakti (2003) dibagi menjadi empat kelas yaitu sangat sesuai (S1), cukup sesuai (S2), sesuai marginal (S3), dan tidak sesuai $(\mathrm{N})$.

Analisis beban limbah yang dilakukan pada penelitian ini mengacu pada metode Ackefors \& Enell (1990) dalam Barg (1992) yaitu dengan perhitungan persamaan untuk beban total nutrien. Sedangkan analisis kapasitas lingkungan dalam menerima beban limbah dihitung berdasarkan pada formula Rachmansyah et al., (2005); Tran \& Nguyen (2006) dalam Nguyen et al. (2013) yang dimodifikasi.

\section{Hasil dan Pembahasan}

Secara umum, perairan di Bumi Dipasena Sejahtera terbagi menjadi 3 jenis perairan yaitu inlet, outlet, dan tambak. Selama penelitian, data yang didapatkan di lapangan meliputi data kualitas air yang diambil di 7 stasiun serta data produksi budidaya yang dilakukan di tiga tambak berbeda. Sistem budidaya udang vaname selama penelitian di Bumi Dipasena Sejahtera menggunakan sistem budidaya semi intensif. Tingkat produksi budidaya diperoleh dari tiga tambak berbeda yang disajikan pada Tabel 1. Hasil menunjukkan bahwa terdapat variasi produksi yang berbeda. Produksi tertinggi diperoleh di tambak 3 meskipun memiliki tingkat kelulushidupan yang lebih rendah dibandingkan tambak 2 . Sedangkan tingkat produksi terendah diperoleh dari tambak 1 dengan tingkat kelulushidupan yang paling rendah.

Tabel 1. Data Produksi Udang Vaname Selama Periode Penelitian

\begin{tabular}{cccc}
\hline \multicolumn{4}{c}{ Data Budidaya Udang Vaname } \\
\hline Variabel & Tambak 1 & Tambak 2 & Tambak 3 \\
\hline Padat tebar (Density) (ekor) & 45.000 & 45.000 & 45.000 \\
Populasi (Population) (ekor) & 30.105 & 35.505 & 32.265 \\
Produksi (Production) (kg) & 250 & 323 & 358 \\
ABW (Average Body Weight) (g) & 8,3 & 9,09 & 11,1 \\
SR (Survival Rate) (\%) & 66,9 & 78,9 & 71,7 \\
FR (Feeding Rate) (\%) & 3,15 & 3,15 & 3,15
\end{tabular}




\begin{tabular}{cccc} 
Total pakan $($ Feed $)(\mathrm{kg})$ & 325 & 452,2 & 465,4 \\
FCR (Feed Convertion Ratio) & 1,3 & 1,4 & 1,3 \\
Kandungan karkas udang (\%) & 1,85 & 2,07 & 2,63 \\
\hline
\end{tabular}

Kegiatan budidaya yang dilakukan selama penelitian ini menggunakan sistem budidaya semi intensif. Hasil produksi yang didapatkan sekitar $250 \quad-358$ $\mathrm{kg} /$ tambak atau $0,125-0,179 \mathrm{~kg} / \mathrm{m}^{2}$ dengan tingkat kelulushidupan (Survival Rate) 66,9 - 78,9\%. Hasil ini lebih rendah jika dibandingkan dengan produksi yang didapatkan oleh Hakim (2018) dan standar baku mutu yang ditetapkan oleh KKP (2016). Variasi produksi yang terjadi dipengaruhi oleh nilai SR yang berbeda di ketiga tambak. Nilai SR tertinggi didapatkan di tambak 2 , sedangkan yang terendah adalah tambak 1. Menurut Cahyono (2009), ada dua faktor yang mempengaruhi tinggi rendahnya kelulushidupan dalam budidaya yaitu faktor abiotik dan biotik. Faktor abiotik terdiri dari faktor fisika dan kimia di suatu perairan atau sering disebut dengan kualitas air. Rendahnya SR di tambak 1 disebabkan oleh kondisi kualitas air yang lebih rendah dibandingkan dengan dua tambak lainnya.
Rendahnya kualitas air di tambak juga dipengaruhi oleh limbah nutrien yang berasal dari pakan.

McDonald et al. (1996) menyebutkan bahwa dalam kegiatan budidaya secara komersial sebanyak $30 \%$ dari total pakan yang diberikan tidak dikonsumsi. Selanjutnya, sekitar $25-30 \%$ dari pakan yang dikonsumsi tersebut akan diekskresikan. Sisa pakan yang dihasilkan ini akan menjadi beban limbah yang mempengaruhi proses metabolik di dalam tambak, sehingga konsentrasi senyawa beracun seperti amonia dan nitrit menjadi tinggi. Selain itu, sisa pakan ini juga akan mempengaruhi beban limbah yang dihasilkan tambak ke lingkungan perairan. Kontribusi limbah nutrien yang berasal dari tambak ini dipengaruhi oleh biomassa udang yang dihasilkan dan nilai konversi pakan. Semakin tinggi tingkat efisiensi pakan, maka output nutrien sebagai beban limbah semakin rendah.

Tabel 2. Nutrien dari Tambak Berbeda

\begin{tabular}{cccc}
\hline Tambak & $\begin{array}{c}\text { Produktivitas } \\
\text { (ton) }\end{array}$ & $\begin{array}{c}\text { Beban limbah } \\
(\mathbf{k g ~ N})\end{array}$ & $\begin{array}{c}\text { Beban limbah/ton produksi } \\
\text { udang (kg N/ton) }\end{array}$ \\
\hline 1 & 0,25 & 71,43 & 285,70 \\
2 & 0,32 & 99,11 & 297,33 \\
3 & 0,36 & 99,48 & 298,44 \\
\hline
\end{tabular}

Hasil perhitungan beban limbah nutrien (Tabel 2) menunjukkan bahwa produksi yang tinggi menghasilkan beban limbah yang juga tinggi. Hal ini disebabkan karena semakin tinggi udang yang dihasilkan maka jumlah pakan yang digunakan juga tinggi. Penggunaan pakan yang tinggi tersebut menyebabkan jumlah limbah nutrien yang dihasilkan semakin tinggi.

Pada dasarnya lingkungan memiliki kemampuan untuk memulihkan diri secara alami, namun 
terdapat batasan tertentu yang perlu diperhatikan untuk menjaga keseimbangan lingkungan. Hal inilah yang akhirnya menjadi alasan penting untuk mengetahui kapasitas lingkungan dalam menerima beban limbah. Dalam penelitian ini, pendugaan volume perairan yang menampung beban limbah ini mengacu pada kondisi aliran air di saluran outlet serta lokasi tambak budidaya. Beban limbah yang dihasilkan dari tambak di Bumi Dipasena dibuang melalui saluran outlet yang mengarah ke lokasi penampung limbah di pesisir timur kawasan pertambakan Bumi Dipasena dengan melalui aliran Sungai Sidang yang bermuara di perairan Laut Jawa. Estimasi volume perairan yang terdampak beban limbah sekitar $75.000 .000 \mathrm{~m}^{3}$. Hasil Pendugaan volume perairan yang terdampak beban limbah (Tabel 3) berdasarkan data tambak yang digunakan masing-masing adalah $260.325 \mathrm{~kg} \mathrm{~N}, 255.375 \mathrm{~kg} \mathrm{~N}$, dan $256.650 \mathrm{~kg} \mathrm{~N}$.

Tabel 3. Kapasitas Lingkungan Penerima Limbah

\begin{tabular}{cccc}
\hline Variabel & Tambak 1 & Tambak 2 & Tambak 3 \\
\hline Konsentrasi N yang di perkenankan $\left(\mathrm{mg} / \mathrm{m}^{3}\right)$ & 4.000 & 4.000 & 4.000 \\
Konsentrasi N insitu $\left(\mathrm{mg} / \mathrm{m}^{3}\right)$ & 529 & 595 & 578 \\
Kapasitas lingkungan menerima limbah $(\mathrm{kg} \mathrm{N})$ & 260.325 & 255.375 & 256.650 \\
\hline
\end{tabular}

Pendugaan volume perairan penampung limbah ini dapat digunakan untuk mengetahui estimasi daya tampung lingkungan untuk kegiatan budidaya yang direpresentasikan dalam jumlah tambak. Hasil perhitungan (Tabel 4) menunjukkan bahwa semakin tinggi produksi tambak maka jumlah tambak yang dapat beroperasi semakin sedikit. Pada tingkat produktivitas 0,25 ton/petak, jumlah tambak yang ideal beroperasi adalah 911 unit tambak dengan estimasi total produksi 227,8 ton udang. Selanjutnya dengan tingkat produktivitas 0,32 dan 0,36 ton/petak, maka tambak yang ideal beroperasi masing masing adalah 671 dan 571 unit tambak dengan total produksi 214,75 dan 215 ton udang.

Tabel 4. Estimasi Kapasitas Lingkungan Perairan di Bumi Dipasena Sejahtera

\begin{tabular}{cccc}
\hline \multirow{2}{*}{ Item } & \multicolumn{3}{c}{ Tambak } \\
\cline { 2 - 4 } & $\mathbf{1}$ & $\mathbf{2}$ & $\mathbf{3}$ \\
\hline Padat penebaran $\left(\mathrm{ekor} / \mathrm{m}^{2}\right)$ & 23 & 23 & 23 \\
Produksi udang $\left(\mathrm{kg} / 2000 \mathrm{~m}^{2}\right)$ & 250 & 323 & 358 \\
Volume badan air penerima limbah $\left(\mathrm{m}^{3}\right)$ & 75.000 .000 & 75.000 .000 & 75.000 .000 \\
Beban limbah $(\mathrm{kg})$ & 71,43 & 99,11 & 99,48 \\
Kapasitas lingkungan menerima limbah $(\mathrm{kg} \mathrm{TN})$ & 260.325 & 255.375 & 256.650 \\
Beban limbah TN (kg N/ton udang) & 285,7 & 297,33 & 298,44 \\
Daya dukung (ton udang) & 227,8 & 214,75 & 215 \\
Tambak yang diperkenankan beroperasi di & 911 & 671 & 597 \\
Bumi Dipasena Sejahtera (petak tambak) & & &
\end{tabular}

Secara umum, perairan di Kampung Bumi Dipasena Sejahtera terbagi menjadi 3 jenis perairan yaitu inlet (stasiun I, II, III, dan VII), outlet 
(stasiun IV, V, VI), dan tambak (1, 2, 3). Hasil pengukuran kualitas air selama penelitian (Tabel 5) menunjukkan bahwa terdapat perbedaan kualitas air di inlet, outlet dan tambak. Perbedaan tersebut terlihat pada salinitas, oksigen terlarut, dan TSS. Nilai salinitas di outlet lebih rendah dibandingkan dengan di inlet dan tambak. Hal tersebut disebabkan karena adanya pola aliran air yang berbeda di ketiga lokasi tersebut. Selain itu, curah hujan yang tinggi serta lokasi outlet yang bersentuhan langsung dengan sungai juga mempengaruhi rendahnya salinitas di perairan outlet. Hal ini sesuai dengan pendapat Anggoro (1984) yang menyatakan bahwa salinitas suatu perairan dipengaruhi oleh adanya aliran air laut, daratan, curah hujan, dan pasang surut. Hasil pengukuran lain menunjukkan bahwa kondisi oksigen terlarut di outlet lebih rendah dibandingkan dengan di inlet dan tambak. Rendahnya oksigen terlarut biasanya dipengaruhi oleh salinitas dan temperatur yang tinggi. Namun, hasil pengukuran yang telah dilakukan menunjukkan jika tingkat salinitas outlet termasuk rendah dengan kondisi suhu yang normal.

Tabel 5. Kisaran Kualitas Air di Bumi Dipasena Sejahtera

\begin{tabular}{ccccccccc}
\hline Stasiun & $\begin{array}{c}\text { Suhu } \\
\left({ }^{\circ} \mathrm{C}\right)\end{array}$ & $\mathbf{p H}$ & $\begin{array}{c}\text { Salinitas } \\
(\% \mathrm{\%})\end{array}$ & $\begin{array}{c}\text { DO } \\
(\mathrm{mg} / \mathrm{l})\end{array}$ & $\begin{array}{c}\text { Amonia } \\
(\mathrm{mg} / \mathrm{l})\end{array}$ & $\begin{array}{c}\text { Nitrit } \\
(\mathrm{mg} / \mathrm{l})\end{array}$ & $\begin{array}{c}\text { TSS } \\
(\mathrm{mg} / \mathrm{l})\end{array}$ & $\begin{array}{c}\text { Nitrat } \\
(\mathrm{mg} / \mathrm{l})\end{array}$ \\
\hline I & 29 & 7,3 & 15 & 11 & 0,171 & 0,775 & 83 & 5,75 \\
II & 28 & 7,5 & 15 & 14 & 0,325 & 1,5 & 274 & 11,16 \\
III & 28 & 7 & 15 & 5 & 0,424 & 1,56 & 385 & 11,63 \\
IV & 27 & 8.6 & 0,6 & 2 & 0,368 & 1,73 & 493 & 12,87 \\
V & 29 & 10.45 & 0,5 & 2 & 0,415 & 1,82 & 431 & 13,53 \\
VI & 26 & 8,5 & 0 & 2 & 0,369 & 1,67 & 395 & 12,44 \\
VII & 26 & 7,3 & 15 & 8 & 0,486 & 1,62 & 173 & 12,06 \\
Tambak 1 & 31 & 7,6 & 26 & 8 & 0,127 & 1,45 & 211 & 10,83 \\
Tambak 2 & 30 & 6,6 & 20 & 11 & 0,262 & 1,31 & 206 & 9,78 \\
Tambak 3 & 28 & 6,5 & 15 & 8 & 0,172 & 0,909 & 27 & 6,75 \\
\hline
\end{tabular}

Berdasarkan hal tersebut, faktor utama yang paling mungkin mempengaruhi kandungan oksigen terlarut di outlet adalah hasil pembusukan yang berasal dari limbah tambak. Warjdono (1974) menyatakan bahwa oksigen terlarut juga akan menurun akibat dari pembusukan dan respirasi dari biota air yang kemudian diikuti dengan meningkatnya $\mathrm{CO}^{2}$ serta menurunnya $\mathrm{pH}$ dalam air. Selain oksigen terlarut, konsentrasi padatan tersuspensi (TSS) juga berbeda secara signifikan antara perairan outlet dengan inlet dan tambak. Kandungan padatan tersuspensi yang tinggi menjadi salah satu faktor yang mempengaruhi penurunan konsentrasi oksigen terlarut. Hal ini disebabkan karena padatan tersuspensi yang tinggi menyebabkan tingkat kekeruhan dalam air meningkat sehingga berdampak pada terganggunya proses fotosintesis sebagai salah satu sumber oksigen di air.

Hasil analisis kesesuaian perairan (Tabel 6 dan 7) menunjukkan bahwa perairan inlet dan tambak di lokasi penelitian masuk ke dalam kategori sesuai marginal (S3) dengan nilai skor $66 \%$ dan $72 \%$. Menurut Trisakti (2003), kelas sesuai marginal memiliki faktor pembatas yang 
berpengaruh secara nyata terhadap penggunaan suatu daerah. Parameter yang menjadi faktor pembatas di kedua perairan ini adalah nitrit. Nitrit merupakan senyawa intermediet antara amonia dan nitrat berupa senyawa nitrogen anorganik yang berbahaya karena kemampuannya dalam mengikat hemolymph pada udang sehingga mengganggu proses absorbsi oksigen. Hasil penelitian menunjukkan bahwa konsentrasi nitrit di perairan inlet dan tambak cukup tinggi yaitu mencapai 1,42 $\mathrm{mg} / \mathrm{l}$ di tambak dan 1,232 mg/l di tambak. Nilai konsentrasi nitrit tersebut telah melebihi ambang batas maksimal yang telah ditetapkan oleh Kementrian Perikanan dan Kelautan (2016) yakni sebesar $1 \mathrm{mg} / \mathrm{l}$.

Tabel 6. Pembobotan dan Skoring Kesesuaian Perairan Inlet di Bumi Dipasena Sejahtera

\begin{tabular}{lccccccc}
\hline Variabel/Stasiun & I & II & III & VII & $\begin{array}{c}\text { Nilai } \\
(\mathbf{A})\end{array}$ & $\begin{array}{c}\text { Bobot } \\
(\mathbf{B})\end{array}$ & Skor (A) x (B) \\
\hline Suhu $\left({ }^{\circ} \mathrm{C}\right)$ & 29 & 28 & 28 & 26 & 3 & 3 & 9 \\
$\mathrm{pH}$ & 7,3 & 7,5 & 7 & 7,3 & 3 & 3 & 9 \\
Salinitas (\%) & 15 & 15 & 15 & 15 & 5 & 3 & 15 \\
DO (mg/l) & 11 & 14 & 5 & 8 & 3 & 3 & 9 \\
Amonia (mg/l) & 0,171 & 0,325 & 0,424 & 0,486 & 3 & 2 & 6 \\
Nitrit (mg/l) & 0,775 & 1,5 & 1,56 & 1,62 & 1 & 2 & 2 \\
TSS (mg/l) & 83 & 274 & 385 & 173 & 3 & 2 & 6 \\
Nitrat (mg/l) & 5,75 & 11,16 & 11,63 & 12,06 & 5 & 2 & 10 \\
\hline & \multicolumn{7}{c}{ Total Skoring } \\
\end{tabular}

Tabel 7. Pembobotan dan Skoring Kesesuaian Perairan Tambak di Bumi Dipasena Sejahtera

\begin{tabular}{|c|c|c|c|c|c|c|}
\hline Variabel/Stasiun & $\begin{array}{c}\text { Tambak } \\
1 \\
\end{array}$ & $\begin{array}{c}\text { Tambak } \\
2 \\
\end{array}$ & $\begin{array}{c}\text { Tambak } \\
3 \\
\end{array}$ & $\begin{array}{l}\text { Nilai } \\
\text { (A) }\end{array}$ & $\begin{array}{c}\text { Bobot } \\
\text { (B) }\end{array}$ & Skor (A) x (B) \\
\hline Suhu $\left({ }^{\circ} \mathrm{C}\right)$ & 31 & 30 & 28 & 5 & 2 & 10 \\
\hline $\mathrm{pH}$ & 7,6 & 6,6 & 6,5 & 3 & 2 & 6 \\
\hline Salinitas (\%o) & 26 & 20 & 15 & 5 & 2 & 10 \\
\hline $\mathrm{DO}(\mathrm{mg} / \mathrm{l})$ & 8 & 11 & 8 & 3 & 3 & 9 \\
\hline Amonia (mg/l) & 0,127 & 0,262 & 0,172 & 5 & 3 & 15 \\
\hline Nitrit (mg/l) & 1,45 & 1,31 & 0,909 & 1 & 3 & 3 \\
\hline TSS (mg/l) & 211 & 206 & 27 & 3 & 3 & 9 \\
\hline Nitrat (mg/l) & 10,83 & 9,78 & 6,75 & 5 & 2 & 10 \\
\hline \multicolumn{6}{|c|}{$\begin{array}{c}\text { Total Skoring } \\
\text { Nilai Skor }(\%)\end{array}$} & $\begin{array}{l}72 \\
72\end{array}$ \\
\hline
\end{tabular}

Tingginya konsentrasi nitrit di perairan inlet dan tambak tersebut berkaitan erat dengan proses nitrifikasi yang terjadi dalam air. Nitrifikasi merupakan proses oksidasi yang merubah senyawa amonia menjadi nitrit atau nitrat dengan melibatkan bakteri autotrofik
(Hastuti, 2011). Dalam proses nitrifikasi, amonia akan berinteraksi dengan oksigen dan menghasilkan nitrit, kemudian berinteraksi dengan bakteri jenis lain dan berubah menjadi nitrat. Hasil pengukuran menunjukkan konsentrasi oksigen terlarut di inlet dan tambak cukup 
tinggi, kondisi tersebut memicu proses pembentukan nitrit dan nitrat dari amonia (nitrifikasi) menjadi lebih cepat. Hal ini ditunjukkan dengan tingginya konsentrasi nitrit dan nitrat di inlet dan tambak yang disertai dengan konsentrasi amonia yang lebih rendah.

Hal tersebut sesuai dengan pendapat Komarawidjaja (2006) yang menyatakan bahwa tingginya konsentrasi oksigen terlarut menyebabkan proses pembentukan nitrit di perairan menjadi lebih cepat. Selain oksigen terlarut, tingginya masukan nitrogen anorganik dari perairan pesisir dan akumulasi sisa pakan juga mempengaruhi konsentrasi nitrit dan nitrat di perairan. Nitrogen anorganik yang masuk ke inlet diduga merupakan pengaruh dari adanya akumulasi beban limbah budidaya yang terjadi di pesisir. Hal ini dapat terjadi karena lokasi perairan pesisir yang digunakan sebagai daerah penampung limbah merupakan lokasi yang masih sama dengan sumber air yang masuk ke dalam saluran inlet.

Hasil analisis pada penelitian ini menunjukkan bahwa peningkatan produktivitas tambak berpotensi menurunkan jumlah tambak yang beroperasi. Produktivitas yang semakin tinggi akan meningkatkan jumlah pakan yang digunakan, selanjutnya jumlah limbah yang dihasilkan akan ikut meningkat sehingga menyebabkan terjadinya penurunan kualitas air. Jika hal ini tidak diantisipasi dengan perlakuan khusus tertentu, maka hal tersebut akan berpotensi besar menyebabkan penurunan tingkat kelulushidupan udang sehingga produksi udang menjadi turun.
Untuk meningkatkan produksi budidaya dibutuhkan kualitas air yang baik. Hal ini dapat dicapai dengan memberikan perlakuan khusus terhadap air yang masuk maupun keluar dari lokasi budidaya. Salah satu metode yang dapat membantu perbaikan kualitas air dalam tambak maupun di lingkungan sekitar adalah dengan menerapkan sistem pengelolaan limbah yang baik disertai dengan manajemen kualitas air budidaya. Penerapan sistem pengolahan limbah tersebut dapat berupa monitoring kualitas air maupun penerapan sistem tandon. Peraturan Kementerian Kelautan dan Perikanan (2016) menyatakan bahwa setiap lokasi budidaya harus memiliki petak tandon minimal 30\% dari volume air pemeliharaan baik secara individu maupun kolektif. Hal ini bertujuan untuk mengurangi jumlah masukan limbah ke dalam tambak sehingga memperbesar kemungkinan untuk mendapatkan hasil produksi yang lebih tinggi. Selanjutnya, pengelolaan lingkungan untuk budidaya semi intensif meliputi pemeliharaan tanaman mangrove di pesisir pantai yang menjadi daerah buangan limbah budidaya serta penanaman mangrove di saluran outlet yang dipengaruhi oleh pasang surut dan aliran nutrien. Hal ini berkaitan dengan fungsi mangrove sebagai penyangga (buffer) dan penyaring bagi ekosistem perairan. Pa'Ez-Osuna (2001) menyatakan bahwa mangrove memiliki fungsi sebagai filter di daerah pertambakan. Selain itu, pengujian kandungan residu obat ikan, bahan kimia, dan kontaminan di laboratorium perlu dilakukan untuk memonitoring kandungan air buangan limbah. 


\section{Kesimpulan dan Saran}

Kondisi perairan inlet dan tambak di Bumi Dipasena Sejahtera tergolong dalam kelas sesuai marginal (S3) dengan parameter yang menjadi faktor pembatas di kedua lokasi perairan tersebut adalah konsentrasi nitrit yang tinggi. Beban limbah yang dihasilkan oleh tambak dengan produktivitas 0,25 ton/petak adalah $71,43 \mathrm{~kg} \mathrm{~N}$. Sedangkan dengan produktivitas 0,32 dan 0,36 ton/petak beban limbah yang dihasilkan adalah 99,11 dan 99,48 kg N. Hasil analisis kapasitas lingkungan menunjukkan bahwa peningkatan produktivitas tambak berpotensi menurunkan jumlah tambak yang beroperasi. Produktivitas yang semakin tinggi berpotensi meningkatkan jumlah limbah yang akan menyebabkan penurunan kualitas air.

\section{Daftar Pustaka}

Anggoro, S. 1984. Tropi Tropic Saprobic Analisis: Metode Evaluasi Kelayakan Lokasi Budidaya Biota Aquatic. Jurusan Ilmu Perairan. Fakultas Pasca Sarjana. IPB, Bogor.

Avnimelech, Y. 2000. Nitrogen control and protein recycling: Activated suspension ponds. Advocate, 3(2): 23-24.

Barg, U.C. 1992. Guidelines for the promotion of environmental management of coastel aquaculture development. FAO Fisheries Technical Paper 328, FAO, Rome, 122 pp.

Boyd, C.E., Massaut, L., \& Weddig, L.J. 1998. Towards reducing environmental impacts of pond aquaculture.

INFOFISH

International 2/98, p. 27-33.

Departemen Kelautan dan Perikanan. 2002. Modul Sosialisasi dan Orientasi Penataan Ruang Laut, Pesisir dan Pulau-Pulau Kecil. Ditjen Pesisir dan PulauPulau Kecil. Direktorat Tata Ruang Laut, Pesisir dan PulauPulau Kecil, Jakarta.

Daud, A. 2018. KEIN Minta Jokowi Jadikan Tambak Udang Dipasena Proyek Strategis. https://katadata.co.id/berita/201 /03/kein-minta-jokowi-jadikantambak-udang-dipasena-proyek strategis

Fadilasari. 2012. Dipasena, Kemitraan, Konflik, dan Perlawanan Petani Udang. Sijado Institute, Bandar Lampung

Hakim, L. 2018. Performa Budidaya Udang Vaname (Litopeneaus vannamei) Semi Intensif di Desa Purworejo Kecamatan Pasir Sakti Kabupaten Lampung Timur. Skripsi. Universitas Lampung, Lampung

Hastuti, Y.P. 2011. Nitrifikasi dan Denitrifikasi di Tambak. Jurnal Akuakultur Indonesia, 10(1): 89-98.

Horowitz, A. \& Horowitz, S. 2000. Microorganisms and feed management in aquaculture. Global Aquaculture Advocate, 3(2): 33-34.

Kementerian Kelautan dan Perikanan Republik Indonesia. 2016. Peraturan Menteri Kelautan dan Perikanan Nomor 75/Permen Kp/2016 Tentang Pedoman Umum Pembesaran Udang Windu (Penaeus 
Monodon) dan Udang Vaname (Litopenaeus vanamei).

Kementerian Kelautan dan Perikanan RI, Jakarta.

Komarawidjaja, W. 2006. Pengaruh Perbedaan Dosis Oksigen terlarut (DO) Pada Degradasi Amonium Kolam Kajian Budidaya Udang. Jurnal Hidrosfer, 1(1): 32-37

Montoya, R. \& Velasco, M. 2000. Role of bacteria on nutritional and management strategies in aquaculture systems. Global Aquaculture Advocate, 3(2): 35-36.

$\mathrm{Pa}^{\prime}$ Ez-Osuna, F. 2001. The Environmental Impact of Shrimp Aquaculture: Causes, Effects, and Mitigating Alternatives. Environmental Management, 28(1): 131- 140

Poxton, M. 2003. Water quality. In: Lucas, J.S. and Southgate, P.C. (Eds.), Aquaculture: Farming Aquatic Animals and Plans. Blackwell Publishing Ltd., Oxford. p. 47-73.

Rachmansyah, M. \& Taruna, M. (2005). Pendugaan daya dukung Teluk Awarange bagi budidaya bandeng dalam keramba jaring apung. Jurnal Penelitian Perikanan Indonesia, 11(1): 81- 93.

Trisakti, B. 2003. Pemanfaatan Penginderaan Jauh Untuk Budidaya Perikanan Pantai. Teknologi Penginderaan Jauh dalam Pengelolaan Wilayah Pesisir Dan Lautan, Bab 4: 3444

Warjdono, S.T.H. 1974. Manajemen Kualitas Air. Fakultas Perikanan dan Ilmu Kelautan, IPB, Bogor. 